\title{
The helminth community of the Iberian hare, Lepus granatensis (Lagomorpha: Leporidae), in the province of Granada, Spain
}

\author{
J. M. SEGOVIA ${ }^{1}$, T. VILA ${ }^{1}$, J. M. VARGAS ${ }^{2}$, M. V. FUENTES ${ }^{3 *}$, C. FELIU $^{1,4}$
}

\begin{abstract}
${ }^{1}$ Laboratori de Parasitologia, Facultat de Farmàcia, Universitat de Barcelona, Avinguda Diagonal s/n, Barcelona, E-08028, Spain; ${ }^{2}$ Departamento de Biología Animal, Universidad de Málaga, Campus de Teatinos s/n, Málaga, E-29071, Spain; ${ }^{3}$ Departament de Biologia Cel-lular i Parasitologia, Facultat de Famàcia, Universitat de València, Avinguda de Vicent Andrés Estellés s/n, Burjassot, València, E-46100, Spain, "E-mail: mario.v.fuentes@uv.es;

${ }^{4}$ IRBIO, Institut de Recerca de la Biodiversitat, Universitat de Barcelona, Avinguda Diagonal 645,
\end{abstract} Barcelona, E-08028, Spain

\begin{abstract}
Summary
The helminth community of the Iberian hare, Lepus granatensis, in the southern Spanish province of Granada was analysed, thorough the study of 487 individuals shot by hunters between November 1998 and October 1999. Six helminth species were found: Mosgovoyia pectinata (Cestoda); Trichostrongylus retortaeformis, Nematodiroides zembrae, Nematodirus sp., Passalurus ambiguus and Micipsella numidica (Nematoda). N. zembrae and M. pectinata $(62.4 \%$ and $17.2 \%$, respectively) were the only component species found. The predominance of helminth species with a direct life cycle is noteworthy. These two component species were significantly influenced by season of capture. Other factors, such as host age and municipality of capture, influenced the prevalences and/or abundances of the component species, while host sex did not exert any important role. These variations, determined by extrinsic and/or intrinsic factors, in the helminth community could be related to the ecology of the Iberian hare, mainly diet, habitat and behaviour.
\end{abstract}

Keywords: Helminth community; Iberian hare; Lepus granatensis; Granada; Spain

\section{Introduction}

Lepus granatensis Rosenhauer, 1856 is an endemic species of the Iberian Peninsula, which lives in parapatry with other representatives of the genus, $L$. europaeus and $L$. castroviejoi. Among them, L. granatensis shows the broadest Iberian distribution, occupying much of the Iberian Peninsula except for a strip that runs from the northwest to the northeast; the mouth of the river Ebro being its eastern limit. This lagomorph was also introduced in the south of France as a game species in the past few decades. The population of the Iberian hare is stable within its typical area of distribution (Duarte, 2000; Muñoz-Cobo \& Moreno, 2004; Acevo et al., 2012).
Information available on infectious diseases affecting $L$. granatensis is scarce, in contrast to the abundance of references related to the sympatric lagomorph, Oryctolagus cuniculus. In particular, helminthological studies on $L$. granatensis from the south of Spain are limited to those of Moreno et al. (1979) and Martínez-Gómez et al. (1987), who studied two batches of 42 and 45 hosts from Cordoba, respectively. In central Spain, García-Romero et al. (2001) analysed 63 Iberian hares, while Alzaga et al. (2008) analysed a similar batch $(\mathrm{n}=68)$ from Castille-La Mancha. Concerning the northern range, Molina (1998) and Bordes et al. (2007) provided helminthological data from Navarre and southern France ( $\mathrm{n}=39$ and $\mathrm{n}=47$, respectively). These studies, most of them focused on areas that constitute the geographical limit for the species (Molina, 1998; Bordes et al., 2007), made the characterization of the helminthfauna of L. granatensis in distant points of the Iberian Peninsula possible. However, there is a lack of parasitological studies on southern Spain, where L. granatensis is particularly abundant.

Parasitological studies have proved to be useful in the elucidation of biological features related to lagomorphs (Newey \& Thirgood, 2004; Newey et al., 2005; Eira et al., 2007; Townsend et al., 2009). In the case of the Iberian hare, the only study of such characteristics is that by Alzaga et al. (2008), who analysed the relationship between parasite burdens and its ability to escape from predators. However, further analyses concerning the correlation between parasitism and other host-related factors are still required (Fernández et al., 2008; Paupério \& Célio, 2008). This study aims to contribute to the knowledge on the helminthfauna of the Iberian hare in southern Spain through the survey of a large batch of the host. Moreover, an ecological analysis has also been carried out in order to assess variations in its helminth community, taking into account intrinsic and extrinsic factors. 


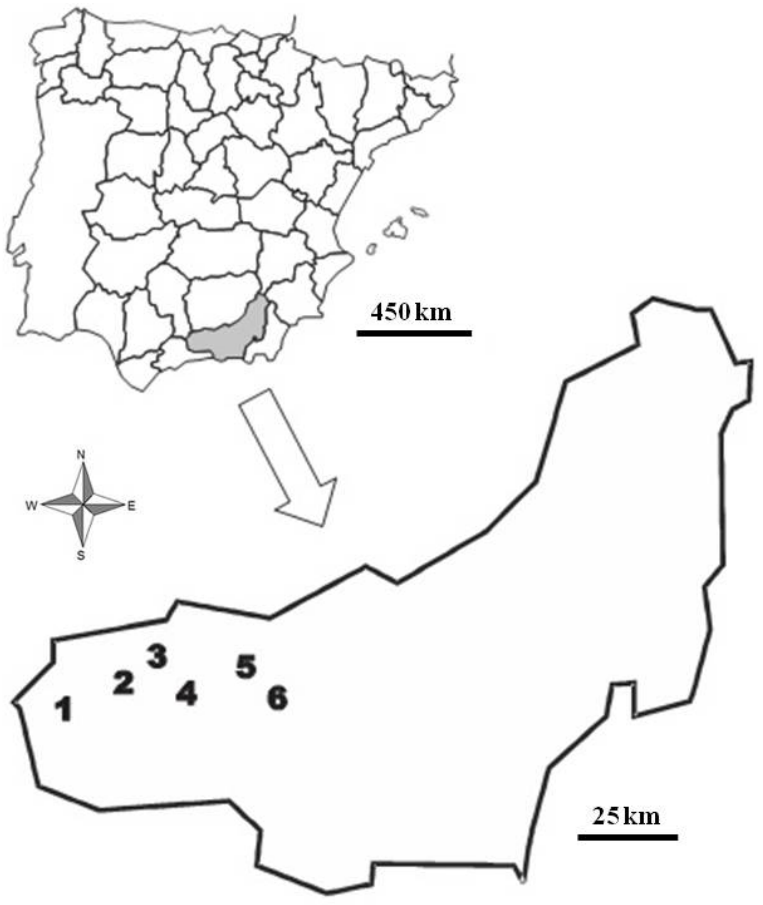

Fig. 1. Geographical location of municipalities in the province of Granada (Spain) where the sample of Lepus granatensis was collected.

1, Loja; 2, Alomartes; 3, Illora; 4, Cijuela; 5, Caparacena; 6, Albolote

\section{Material and methods}

A batch of 487 Iberian hares (258 males and 229 females) shot by hunters between November 1998 and October 1999 , along the four seasons, i.e. autumn $(n=136)$, winter $(n=145)$, spring $(n=117)$ and summer $(n=89)$, was analysed (Table 1). The sample was obtained by legal hunting methods, in compliance with Spanish laws and Annex IV of the Berne Convention on the Conservation of European Wildlife and Natural Habitats. The study area included six municipalities of the province of Granada (Fig. 1): Loja $(n=30)$, Alomartes $(n=106)$, Illora $(n=211)$, Cijuela $(n=86)$, Caparacena $(n=25)$ and Albolote $(n=29)$, located between latitude $37^{\circ} 10^{\prime}-37^{\circ} 18^{\prime} \mathrm{N}$ and longitude $3^{\circ} 38^{\prime}-4^{\circ} 10^{\prime} \mathrm{W}$, where L. granatensis lives in sympatry with $O$. cuniculus. The study area was climatically classified as Mediterranean according to the data provided by the Spanish Meteorological Agency, but with moderate temperatures and rainfall, and without climatic differences between the six municipalities.

Age determination poses some difficulties in Iberian hares, since there are no reference tables for body length, weight, and age, as in the case of the European hare (Péroux, 1995). In spite of this, three subsets of individuals based on body weight were defined: juveniles $<2.000 \mathrm{~g}(\mathrm{n}=103)$; sub-adults between $2.000-2.300 \mathrm{~g}(\mathrm{n}=231)$, and adults $>2.300 \mathrm{~g}(\mathrm{n}=153)$ (Table 1$)$.

The abdominal cavity was opened and the viscera extracted. After that, the mesenteries and the abdominal cavity were examined for the presence of macroparasites. All viscera were systematically checked by using standard helminthological methods (Georgi \& Georgi, 1990). The gastrointestinal tract was divided into four sections (stomach, small intestine, caecum, and colon) which were longitudinally opened with scissors. The content of each section was placed in a $150-\mu \mathrm{m}-\mathrm{mesh}$ sieve and washed under running water. The gastrointestinal contents and any accompanying helminths trapped in the sieve were examined in small amounts in Petri dishes using a stereomicroscope (x10 and x30). All helminths found were removed, counted and preserved in $70 \%$ ethanol. Nematodes were cleared in Amman lactophenol to identify internal structures, while cestodes were stained in Semichon acetocarmine, dehydrated and mounted in Canada balsam. Identification of helminths was made according to previous descriptions (Erhardová, 1957; Skrjabin et al., 1960; Bernard, 1965; Tenora \& Murai, 1978; Durette-Desset, 1979; Hugot et al., 1983; Genov et al., 1990; Beveridge, 1994; Haukisalmi et al., 2010).

The analysis of the helminth community was carried out considering: each particular biological cycle (direct or indirect life cycle), prevalence, mean abundance, median intensity, range and total number of helminths calculated according to Bush et al. (1997).

Where possible, standard non-parametric tests - chisquared $\left(\chi^{2}\right)$, Mann-Whitney $(\mathrm{U})$ and Kruskal-Wallis $(\mathrm{H})$ tests - were applied (Sokal \& Rohlf, 1981). Statistical significance was established at $\mathrm{P}<0.05$.

The role played by intrinsic (host age and sex) and extrinsic (municipality and season of capture) factors in determining helminth prevalences and worm burden (mean abundance) for component species of the Iberian hare were studied. The analysis of helminth prevalences, as the dependent variable, was carried out using binary logistic regression (infected $=1$; uninfected $=0$ ) and the intrinsic and extrinsic factors as independent variables. The analysis of worm burden (expressed by helminth abundance) was carried out using ANOVA (F). As the number of helminths was highly aggregated, the helminth abundance of each species was normalised by the $\ln (\mathrm{x}+1)$ transformation for ANOVA analysis.

The frequency distribution of component species was calculated by means of the Lefkovitch index (L), where $\mathrm{L}=(1 / 45) \operatorname{tang}^{-1}$ (variance/mean)-1 ranging from -1 (positive binomial or uniform distribution), 0 (Poisson or random distribution) to +1 (negative binomial or aggregated distribution).

Table 1. The number of Lepus granatensis examined in Granada, distributed by season of capture, age and sex

\begin{tabular}{lcccccc}
\hline season & \multicolumn{2}{c}{ juvenile } & \multicolumn{2}{c}{ sub-adult } & \multicolumn{2}{c}{ adult } \\
& female & male & female & male & female & male \\
\hline spring & 5 & 16 & 6 & 43 & 40 & 7 \\
summer & 15 & 21 & 9 & 22 & 17 & 5 \\
autumn & 13 & 21 & 41 & 30 & 22 & 9 \\
winter & 2 & 10 & 23 & 57 & 36 & 17
\end{tabular}


Table 2. The composition of the helminth community of Lepus granatensis in Granada. ILC, indirect life cycle; DLC, direct life cycle; $\mathrm{n}$, number of infected hosts; \%, prevalence; CI, confidence interval; SE, standard error.

* Mean abundance, Median intensity and range cannot be reported as not all helminths were collected and counted

\begin{tabular}{|c|c|c|c|c|c|c|c|c|c|}
\hline \multirow[b]{2}{*}{ Helminth species } & \multirow[b]{2}{*}{ Cycle } & \multirow[b]{2}{*}{ Site } & \multicolumn{3}{|c|}{ Prevalence } & \multicolumn{2}{|c|}{ Mean abundance } & \multicolumn{2}{|c|}{ Median intensity } \\
\hline & & & $\mathbf{n}$ & $\%$ & 95\% C.I. & & SE & & Range \\
\hline \multicolumn{10}{|l|}{ CESTODA } \\
\hline Mosgovoyia pectinata & ILC & Intestine & 84 & 17 & $14-21$ & 0.7 & 0.1 & 3 & $1-24$ \\
\hline \multicolumn{10}{|l|}{ NEMATODA } \\
\hline Trichostrongylus retortaeformis & DLC & Intestine & 4 & 1 & $0-2$ & 0.1 & 0.1 & 3 & $1-55$ \\
\hline Nematodiroides zembrae & DLC & Intestine & 304 & 62 & $58-67$ & 31.9 & 3.4 & 16 & $1-516$ \\
\hline Nematodirus sp. & DLC & Intestine & 1 & 1 & $0-2$ & 0.002 & 0.002 & 1 & 1 \\
\hline Passalurus ambiguus & DLC & Intestine & 7 & 1 & $0-2$ & 1.3 & 0.7 & 48 & $4-290$ \\
\hline Micipsella numidica* & ILC & Abdominal cavity & 17 & 3 & $2-5$ & --- & --- & --- & --- \\
\hline
\end{tabular}

StatView 5.0 -SAS Institute Inc and IBM SPSS Statistics 19.0 -SPSS Inc- for Windows were the software packages used for statistical analyses.

\section{Results}

A total of 332 Iberian hares $(68.17 \%)$ was found to be infected with a total of six species: one cestode, Mosgovoyia pectinata (Goeze, 1782) (Anoplocephalidae); and five nematodes, Trichostrongylus retortaeformis (Zeder, 1800) (Trichostrongyloidea), Nematodiroides zembrae (Bernard, 1965) and Nematodirus sp. (Molineidae), Pas- sented helminths with an indirect life cycle, with a statistically significant difference $\left(\chi^{2}=174.051 ; \mathrm{df}=1 ; \mathrm{P}<0.0001\right)$. The analysis of the influence of intrinsic and extrinsic factors on the biodiversity of the helminth community of the Iberian hare showed no remarkable differences among groups. However, concerning age groups, the two component species were the only species reported in juvenile hares. Moreover, concerning municipalities, no species was reported in the municipality of Albolote.

The analysis of prevalence and helminth burden of the two component species showed that populations of $N$. zembrae and $M$. pectinata were affected by: the season (Table 3 )

Table 3. Prevalence and abundance of the helminth component species of the helminth community of Lepus granatensis in Granada grouped by season of capture. $n$, number of infected hosts; \%, prevalence; CI, confidence interval; SE, standard error

\begin{tabular}{|c|c|c|c|c|c|c|c|c|c|c|}
\hline \multirow[b]{3}{*}{ Season } & \multicolumn{5}{|c|}{ Mosgovoyia pectinata } & \multicolumn{5}{|c|}{ Nematodiroides zembrae } \\
\hline & \multicolumn{3}{|c|}{ Prevalence } & \multicolumn{2}{|c|}{ Mean abundance } & \multicolumn{3}{|c|}{ Prevalence } & \multicolumn{2}{|c|}{ Mean abundance } \\
\hline & $\mathbf{n}$ & $\%$ & 95\% C.I. & & SE & $\mathbf{n}$ & $\%$ & 95\% C.I. & & SE \\
\hline Autumn & 44 & 32 & $24-40$ & 1.4 & 0.3 & 79 & 58 & $50-66$ & 15.5 & 3.2 \\
\hline Winter & 21 & 14 & $9-21$ & 0.5 & 0.1 & 106 & 73 & $66-80$ & 47.5 & 7.1 \\
\hline Spring & 14 & 12 & $7-19$ & 0.7 & 0.3 & 73 & 62 & $54-71$ & 6.9 & 1.4 \\
\hline Summer & 5 & 6 & $1-12$ & 0.07 & 0.03 & 46 & 52 & $41-62$ & 64.6 & 12.3 \\
\hline
\end{tabular}

salurus ambiguous (Rudolphi, 1819) (Oxyuridae), Micipsella numidica (Seurat, 1917) (Onchocercidae). Only two of these species were considered as component species (prevalence $>10 \%$ ): $N$. zembrae showed the highest prevalence $(62.42 \%)$ and mean abundance (31.92) of infection, while $M$. pectinata had a prevalence of $17.25 \%$ (Table 2). Thus, the remaining helminth species have to be considered as rare species of the helminth community of the Iberian hare in Granada.

From a biological point of view, $62.63 \%$ of hares presented helminths with a direct life cycle and $20.74 \%$ pre- and the municipality of capture (Table 4); while host age affected $N$. zembrae only, with the highest percentage of infection in sub-adult Iberian hares $(70.13 \%)$.

The role played by these intrinsic and extrinsic factors determining helminth prevalence and abundance of the two component species were ratified by the results of the chisquared test (Table 5) and the binary logistic regression (Table 6) in the case of prevalences, and the Kruskal-Wallis test (Table 5) and ANOVA (Table 7) in the case of abundances.

Table 4. Prevalence and abundance of the helminth component species of the helminth community of Lepus granatensis in Granada grouped by municipality of capture. $n$, number of infected hosts; \%, prevalence; CI, confidence interval; SE, standard error

\begin{tabular}{|c|c|c|c|c|c|c|c|c|c|c|}
\hline \multirow[b]{3}{*}{ Municipality } & \multicolumn{5}{|c|}{ Mosgovoyia pectinata } & \multicolumn{5}{|c|}{ Nematodiroides zembrae } \\
\hline & \multirow[b]{2}{*}{$\mathbf{n}$} & \multicolumn{2}{|c|}{ Prevalence } & \multicolumn{2}{|c|}{ Mean abundance } & \multicolumn{3}{|c|}{ Prevalence } & \multicolumn{2}{|c|}{ Mean abundance } \\
\hline & & $\%$ & 95\% C.I. & & SE & $\mathbf{n}$ & $\%$ & $95 \%$ C.I. & & SE \\
\hline Loja & 1 & 3 & $0-17$ & 0.1 & 0.1 & 10 & 33 & $17-53$ & 3.7 & 2.9 \\
\hline Alomartes & 26 & 25 & $17-34$ & 1.1 & 0.3 & 35 & 33 & $24-43$ & 39.9 & 8.3 \\
\hline Illora & 31 & 15 & $11-21$ & 0.6 & 0.2 & 68 & 32 & $23-39$ & 25.4 & 4.6 \\
\hline Cijuela & 26 & 30 & $21-41$ & 1.0 & 0.2 & 24 & 28 & $19-39$ & 23.9 & 4.8 \\
\hline Caparacena & --- & --- & --- & --- & --- & 7 & 28 & $12-49$ & 151.9 & 25.5 \\
\hline
\end{tabular}


Table 5. Analysis of prevalence and abundance of the helminth component species of the helminth community of Lepus granatensis in Granada grouped by host age and sex, and municipality and season of capture, through the $\chi^{2}$ and the Kruskal-Wallis $(\mathrm{H})$ tests, respectively. $\mathrm{df}$ - degree of freedom. Only statistically significant models are reported.

\begin{tabular}{lccccc}
\hline Independent variables/ helminth species & $\mathbf{d f}$ & $\boldsymbol{\chi}^{\mathbf{2}}$ & $\mathbf{P}$ & $\mathbf{H}$ & $\mathbf{P}$ \\
\hline Mosgovoyia pectinata & & & & & \\
Season & 3 & 33.237 & $<0.0001$ & 33.739 & 0.0001 \\
Municipality & 3 & 16.181 & 0.0010 & 15.710 & 0.0010 \\
Nematodiroides zembrae & & & & & \\
Season & 3 & 12.019 & 0.0073 & 31.335 & 0.0001 \\
Municipality & 4 & 16.492 & 0.0024 & 35.397 & 0.0001 \\
Host age & 2 & 24.960 & $<0.0001$ & 26.930 & 0.0001 \\
\hline
\end{tabular}

The frequency distributions of the two component species showed that both presented a negative binomial distribution: $N$. zembrae $(\mathrm{L}=0.99)$ and $M$. pectinata $(\mathrm{L}=0.85)$.

Table 6. Logistic regression models for prevalences of the helminth component species of the helminth community of Lepus granatensis in Granada grouped by host age and sex, and municipality and season of capture, expressed by $\chi^{2}$ values with associated probabilities $(\mathrm{P})$ for the model created including independent variables. $\mathrm{df}$ - degree of freedom. Only statistically significant models are reported.

\begin{tabular}{|c|c|c|c|}
\hline $\begin{array}{l}\text { Helminth species/independent } \\
\text { variables included in the model }\end{array}$ & df & $\chi^{2}$ & $\mathbf{P}$ \\
\hline Mosgovoyia pectinata & & & \\
\hline $\begin{array}{l}\text { Season \& municipality of capture } \\
\text { Nematodiroides zembrae }\end{array}$ & 8 & 50.520 & $<0.0001$ \\
\hline $\begin{array}{l}\text { Season \& municipality of capture } \\
\& \text { host age }\end{array}$ & 10 & 176.313 & $<0.0001$ \\
\hline
\end{tabular}

\section{Discussion}

The high prevalence of parasitation in the Iberian hare reported in the present study, mainly due to the nematode $N$. zembrae, coincides with other studies carried out concerning this host (Bordes et al., 2007; Alzaga et al., 2008). However, the species richness (only six helminth species were detected in spite of the high number of individuals analysed) is below the results obtained in previous studies undertaken in other areas of Spain, where seven (Moreno et al., 1979), respectively, eight helminth species (Martínez-Gómez et al., 1987; García-Romero et al., 2001) were reported. Above all, the absence of other cestode species is noteworthy. The selection of the preferred habitat (intensive olive tree orchards) by the Iberian hare in the south of Spain (Muñoz-Cobo \& Moreno, 2004) could be a cause of this low diversity, since Bordes et al. (2007) also reported very low species richness in $L$. granatensis in lowland agricultural areas in the northern range of this lagomorph.

N. zembrae, the most prevalent and abundant species, together with $M$. pectinata, are confirmed as the only component species of the helminth community of the Iberian hare in the province of Granada. The high parasitation by the nematode, which had previously been reported in this lagomorph (García-Romero et al., 2001; Bordes et al., 2007), is unsurprising.

One female hare was parasitized by one individual of Nematodirus sp. Species of the genus Nematodirus are common parasites of the small intestine of ruminants. To the best of our knowledge, the finding of one individual of Nematodirus sp. in a female hare is the first report of a species of this genus in Iberian hares. The life cycle of Nematodirus sp. is very similar to N. zembrae, a direct life cycle with a free living larva as infective stage; the only marked difference lies in the pre-patent period, which is longer in Nematodiroides species (Audebert et al., 2002).

The geohelminth $T$. retortaeformis has commonly been reported to parasitize lagomorphs from Spain. Several studies revealed the influence of parasitism by trichostrongilid species on host population dynamics of species of the genus Lepus (Newey et al., 2005; Townsend et al., 2009). The only available data on species of the genus Trichostrongylus parasitizing Iberian hares in southern Spain are

Table 7. Mean abundance of the helminth component species of the helminth community of Lepus granatensis in Granada grouped by host age and sex, and municipality and season of capture, through ANOVA, expressed by F values with associated probabilities (P). df, degree of freedom. Only statistically significant models are reported.

\begin{tabular}{lccc}
\hline Helminth species/Source of variation & df & F & P \\
\hline $\begin{array}{l}\text { Mosgovoyia pectinata } \\
\text { Season of capture }\end{array}$ & 3 & 2.890 & 0.035 \\
Nematodiroides zembrae & & & \\
Season of capture & 3 & 26.204 & $<0.0001$ \\
Municipality of capture & 5 & 22.123 & $<0.0001$ \\
Host age & 2 & 3.644 & 0.027 \\
Season of capture / host sex & 3 & 7.617 & $<0.0001$ \\
Season of capture / host age & 6 & 2.473 & 0.023 \\
Municipality of capture / host sex & 5 & 2.295 & 0.045 \\
Municipality of capture / host sex / host age & 3 & 6.169 & $<0.0001$ \\
\hline
\end{tabular}


those of Moreno et al. (1979), who found a prevalence of $21 \%$ of $T$. retortaeformis in a sample of 42 hares. The limited extent of infection by $T$. retortaeformis found in the present study could be one of the reasons for the high population abundance of the Iberian hare in the study area. When this species is present in the helminth communities of L. granatensis (mainly in winter), it seems to interact with $N$. zembrae, which is expressed as a reduction in the intensity of $T$. retortaeformis. Interactions between $T$. retortaeformis and other parasites of lagomorphs may result in changes in the temporal pattern of the affected species. This effect was reported by Lello et al. (2008) with respect to Graphidium strigosum.

The oxyurid $P$. ambiguus has been reported to parasitize the large intestine and the caecum of rabbits, cottontails and hares all over the world (Harkness et al., 2010). Although this helminth showed the highest mean intensity in the entire host sample, the prevalence reported herein was very low. Similar patterns were reported in other studies on Spanish lagomorphs (García-Romero et al., 2001; Eira et al., 2007).

The filarial worm $M$. numidica, transmitted by an arthropod, had previously been reported to parasitize the Iberian hare (Moreno et al., 1979). In spite of its low prevalence in the analysed host sample, seasonal variations, probably due to vector population fluctuations, were detected, with an increase of its prevalence in summer, with a significant peak in autumn and a marked decrease in winter.

The high dominance of helminth species with a direct life cycle can easily be explained by the high population density and through the scarce, only accidental, ingestion of invertebrate intermediate hosts. On the other hand, the very low prevalence of the oxyurid $P$. ambiguous, a nematode with direct transmission, ageohelminth type, as well as the absence of other helminth species with a direct life cycle, can be related to its supposedly discontinued distribution along agro-climatic areas, as well as by the less sedentary and gregarious character of the Iberian hare when compared to the wild rabbit, O. cunniculus, and through the fact that this hare does not use burrows, consequently this kind of transmission is not favoured (García-Romero et al., 2001). This last aspect is confirmed by the fact that the juvenile hare population was only parasitized by the two component species, and by none of the other three species with a direct life cycle.

Referring to the influence of intrinsic and extrinsic factors on the prevalence and abundance of $M$. pectinata and $N$. zembrae, the influence of the season of capture, with the highest prevalences of $M$. pectinata in autumn, and of $N$. zembrae in winter, may be related to the population increase of the oribatid mite, intermediate host, in summer, ingested by the Iberian hare while grazing, favouring infestation with this cestode species, mainly detected as an adult tapeworm during the following season; and the higher presence of free living nematode larvae, as a consequence of the temperature decrease and the increase of soil humidity from on autumn. On the other hand, these seasonal differences could also be related to the diet of the
Iberian hare. The rate of grass consumption reaches its maximum in winter $(81 \%)$, increasing the probability of acquiring infective stages of both species along the cold season (Paupério \& Célio, 2008). Similar seasonal variations in parasite burdens have been reported for wild rabbits in Spain (García-Romero \& Valcárcel, 1999).

The absence of parasitation in the municipality of Albolote, as well as the presence of $N$. zembrae in Caparacena as the only helminth species detected, seem to be due to the low number of hosts analysed and not due to ecological and/or climatic differences between the municipalities analysed, taking into account the similarity between them and the fact that municipalities represent an artificial geographical division, but it is the only geographical location available within the entire host sample area.

Host sex did not exercise any influence on parasitation. Both helminth component species affect male and female hares equally, agreeing with various studies having reported these two parasites in other Iberian lagomorphs (García-Romero \& Valcárcel, 1999; Molina et al., 1999; Eira et al., 2007).

The effect of parasitic infections on the health of different lagomorph species has been studied by several authors who used the kidney fat index as a measure of physical condition of the host (Eira et al., 2007). Alzaga et al. (2008) reported a significant reduction in fitness and a higher vulnerability to attacks by common predators as a consequence of parasitic infection in Iberian hares. Moreover, helminth burdens also seem to influence the reproductive status of female Iberian hares, which breed throughout the year, although several authors have reported cycles that depend on climatic factors. The results of the present study showed that the highest intensity of helminth infracommunities occurs in autumn and winter, coinciding with the lowest percentage of reproductively active females in the study area.

These findings support the hypothesis that variations in parasite burdens of helminth species affecting Iberian hares throughout the year can exert an effect on the regulation of their populations, either by influencing reproductive cycles or by affecting the body condition of the host. Although potential bilateral effects between helminths and hosts have to be considered, as the immune status of hares can rule the worm burden in the hosts, helminths sometimes only take advantage of the rundown condition of the hare although they do not cause it. These effects are certainly reciprocal between hares and their helminths. The helminth burden depends on the reproductive stage of animals rather than on the reproductive stage of the worm burden. In spite of this, the two component species of the helminth community of the Iberian hare in Granada should be considered well established among the host population, given their prevalences and abundances, as well as their aggregated distribution (negative binomial), and consequently not as a destabilising factor of the Iberian hare population (Anderson \& May, 1978). 


\section{References}

Acevo, P., Melo-Ferreira, J., Real, R., Alves, P. C. (2012): Past, present and future distributions of an iberian endemic, Lepus granatensis : ecological and evolutionary clues from species distribution models. Plos One, 7: e51529. DOI: 10.1371/journal.pone.0051529

Alzaga, V., Vicente, J., Villanua, D., Acevedo, P., CAsas, F., Cortázar, C. (2008): Body condition and parasite intensity correlates with escape capacity in Iberian hares (Lepus granatensis). Behav. Ecol. Sociobiol., 62: 769 - 775. DOI: 10.1007/s00265-007-0502-3

Anderson, R. M., MAY, R. M. (1978): Regulation and stability of host-parasite population interactions. I. Regulatory processes. J. Anim. Ecol., 47: 219 - 247

Audebert, F., Cassone, J., Kerboeuf, D., DuretteDesset, M. C. (2002): The life cycle of Nematodiroides zembrae (Nematoda, Trichostrongylina) in the rabbit. $J$. Parasitol., 88: 898 - 904

BERnARD, J. (1965): Contribution á la connaissance de la faune parasitaire de l'Ile de Zembra. I. Parasites du lapin, Oryctolagus cuniculus. Arch. Inst. Pasteur Tunis, 42: 205 $-223$

Beveridge, I. (1994): Family Anoplocephalidae Cholodkovsky, 1902. In: KHALIL, L. F., JONES, A., BRAY R. A. (Eds) Keys to the Cestode Parasites of Vertebrates. Wallingford, UK, CABI Publishing, pp. 315 - 366

Bordes, F., Langand, J., Feliu, C., Morand, S. (2007): Helminth communities of an introduced hare (Lepus granatensis) and a native hare (Lepus europaeus) in Southern France. J. Wildl. Dis., 43: 747 - 751

Bush, A. O., Lafferty, K. D., Lotz, J. M., ShostaK, H. W. (1997): Parasitology meets ecology on its own terms: Margolis et al. revisited. J. Parasitol., 48: 715 - 718.

DUARTE, J. (2000): Liebre Ibérica Lepus granatensis Rosenhauer, 1856. Galemys, 12: 3 - 14

Durette-Desset, M. C. (1979): Les Nematodirinae (Nematoda) chez les ruminants et chez les lagomorphes. Ann. Parasitol. Hum. Comp., 54: 313 - 329

EIRA, C., Torres, J., MiQuel, J., VingadA, J. (2007): The helminth parasites of the wild rabbit Oryctolagus cuniculus and their effect on host condition in Dunas de Mira, Portugal. J. Helminthol., 81: $239-246$

ERHARDOVÁ, B. (1957): Zur Frage der Wirtspezifizitat einiger Helminthenarten der Familie Trichostrongylidae. Cesk. Parasitol., 4: 121 - 129

Fernández, A., Soriguer, R., CAStien, E., CArro, F. (2008): Reproduction parameters of the Iberian hare Lepus granatensis at the edge of its range. Wildl. Biol., 14: $434-$ 443. DOI: $10.2981 / 0909-6396-14.4 .434$

GArcía-Romero, C., Corchero, J., VAlCÁrCel, F. (2001): Prevalencia de las helmintosis digestivas y cisticercosis en la liebre Ibérica Lepus granatensis en la zona central de España. Ecología, 15: 225 - 232

GARCÍA-ROMERO, C., VALCÁRCEL, F. (1999): Epidemiology of gastrointestinal nematodiasis in wild rabbits (Oryctolagus cuniculus) from Central Spain. Gibier Faune Sauvage, Game Wildl., 16: 159 - 169
Genov, T., Murai, E., Georgiev, B., Harris, E. (1990): The erection of Leporidotaenia n.g. (Cestoda: Anoplocephalidae) for Anoplocephaloides spp. parasitising Leporidae (Lagomorpha). Syst. Parasitol., 26: 107 - 126.

Georgi, J. R., Georgi, M. E. (1990): Parasitology for veterinarians. $5^{\text {th }}$ Edition, Philadelphia, USA, W.B. Saunders Company, 412 pp.

Harkness, J. E., Turner, P. V. Vande Woude, S., WHELER, C. L. (2010): Biology and Medicine of rabbits and rodents. 5th Edition. Iowa, USA, Blackwell Publishing, $472 \mathrm{pp}$.

Haukisalmi, V., Hardman, L. M., Foronda, P., Feliu, C., Henttonen, H. (2010): Systematic relationships of Mosgovoyia Spasskii, 1951 (Cestoda: Anoplocephalidae) and related genera inferred from mitochondrial and nuclear sequence data. Syst. Parasitol., 77: 71 - 79. DOI: 10.1007/s11230-010-9264-9

Hugot, J. P., Bain, O., Cassone, J. (1983): Sur le genere Passalurus (Oxyuridae: Nematoda) parasite de Leporides. Syst. Parasitol., 25: $1065-1075$

Lello, J., Norman, R. A., BoAg, B., Hudson, P. J., FENTON, A. (2008): Pathogen interactions, population cycles, and phase shifts. Am. Nat., 171: 176 - 182. DOI: $10.1086 / 525257$

Martínez-Gómez, F., Hernández-RodríGuez, S., Rey, C., Moreno-Montáñez, T., Acosta, I. (1987): Paracitocoenosis of Lepus capensis in the south of Spain. In: IPPEN, R., SCHOIDEN, H. D. (Eds) Erkrankungen der Zoostiere. Berlin, Germany: Akademic Verlag, pp. 347 352

MolinA, X. (1998): Estudio parasitoecológico de las helmintofaunas de lepóridos (Lagomorpha) en diferentes ecosistemas (peninsulares-insulares). PhD thesis, Spain, Barcelona: Universitat de Barcelona. 243 pp.

Molina, X., CASAnOva, J. C., FeliU, C. (1999): Influence of host weight, sex and reproductive status on helminth parasites on the wild rabbit, Oryctolagus cuniculus, in Navarra, Spain. J. Helminthol., 73: 221 - 225. DOI: http://dx.doi.org/10.1017/S0022149X99000347

Moreno, T., Becerra-Martell, C., Navarrete, I. (1979): Contribución al conocimiento de los parásitos de la liebre Lepus capensis. Rev. Iber. Parasitol., 39: 383 - 393. MuÑOZ-CoBo, J., Moreno, J. (2004): Estudio cualitativo y cuantitativo de las especies de importancia cinegética en cuatro tipos de olivares de Jaén. Bol. San. Veg. Plagas, 30: $133-150$

Newey, S., Shaw, D. J., Kirby, A., Montieth, P., Hudson, P. J., Thirgood, S. J. (2005): Prevalence, intensity and aggregation of intestinal parasites in mountain hares and their potential impact on population dynamics. Int. J. Parasitol., 35: $367-373$

Newey, S., ThIRGOOD, S. (2004): Parasite-mediated reduction in fecundity of mountain hares. R. Soc. Lond., Ser. B: Biol. Sci., 271: S413 - S415

PAUPÉRIO, J., CÉlIO, P. (2008): Diet of the Iberian hare (Lepus granatensis) in a mountain ecosystem. Eur. J. Wildl. Res., 54: 571 - 579. DOI: 10.1007/s10344-0080181-z 
PÉroux, R. (1995): Le lièvre d'Europe. Bull. Mens. Off. Natl Chasse, 204, Special issue: 1 - 96

Skrjabin, K. I., Shikhobalova, N. P., Schulz, R. S. (1960): Trichostrongylids of animals and man. In: Skrjabin, K. I. (Ed) Essentials of Nematodology, Volume III. Jerusalem, Israel: Program for Scientific Translations, $704 \mathrm{pp}$.

SOKAL, R. R., RoHLF, F. J. (1981): Biometry. The principles and practice of statistics in biological research. $2^{\text {nd }}$
Edition, New York, USA, W. H. Freeman and Company., 859 pp.

Tenora, F., Murai, E. (1978): Anoplocephalidae (Cestoda) parasite of Leporidae and Sciuridae in Europe. Acta Zool. Acad. Sci. Hung., 24: 415 - 429

Townsend, S. E., Newey, S., ThiRgood, S. J., MATTHEWs, L., HAYDON, D. T. (2009): Can parasites drive population cycles in mountain hares? R. Soc. Lond., Ser. B: Biol. Sci., 276: 1611 - 1617. DOI: 10.1098/rspb.2008.1669 